\title{
喉頭癌患者に拈忷る発声機能
}

一声門下圧と喉頭効率一

$\begin{array}{lrrr}\text { 岩田 } & \text { 重信・畔柳 } & \text { 久志・竹内 } & \text { 健二 } \\ \text { 戸田 } & \text { 均・小島 } & \text { 秀嗣 } \cdot \text { 岩田 } & \text { 義弘 }\end{array}$

\section{Subglottic Pressure and Laryngeal Efficiency in Patients with Laryngeal Carcinoma}

\author{
Shigenobu Iwata, Hisashi Kuroyanagi, Kenji Takeuchi, \\ Hitoshi Toda, Hidetsugu Kojima and Yoshihiro Iwata
}

(Fujita Health University School of Medicine)

\begin{abstract}
Subglottic pressures and laryngeal efficiencies were measured in 12 normal subjects and 19 patients with laryngeal carcinoma.

In this study, the PS-77 phonatory equipment was used to measure airflow, pitch, intensity levels and subglottic pressure during phonation. Measurements were taken by a miniature pressure transducer through the glottis. These parameters were entered into a PI-201 computer analyzing system. Subjects were requested to phonate the maximum sustained comfortable pitch and intensity level, and to change the intensity levels from lower to louder as far as they could.

During sustained phonation, subglottic pressure showed a mean value of $10.2 \mathrm{cmH}_{2} \mathrm{O}$ in normal subjects and $29.2 \mathrm{cmH}_{2} \mathrm{O}$ in patients with laryngeal carcinoma. The mean value of laryngeal efficiency was $1.47 \pm 1.79 \times 10^{-4}$ in normal subjects and $1.05 \pm 1.82 \times 10^{-4}$ in carcinoma patients. When changing the intensity levels of their voices, parameters such as subglottic pressure, laryngeal resistance, subglottic power and efficiency were increased linearly with the increasing intensity level in normal subjects, but in patients with laryngeal carcinoma, laryngeal efficiency demonstrated lower values and was less changed with increasing intensity levels compared to those of normal subjects.
\end{abstract}

Key words: subglottic pressure, laryngeal efficiency, laryngeal carcinoma

\section{はじめに}

発声機能を評価するらえで声門下圧の測定は 極めて重要であり，これにより多くの基本的情 報を提供することができる. 空気力学的な面よ り，今回，非観血的に声門下圧を抽出し PS-77
発声機能検査装置を併用, 同時記録しコンピ ューターにて自動解析するシステム (PI-100) $)^{1)}$ を開発した。これを用い, 喉頭癌患者の発声機 能の病態を解析する目的で, 声の高さ $(\mathrm{Hz})$, 大 きさ $(\mathrm{dB})$, 呼気流率 $(\mathrm{ml} / \mathrm{sec})$ 声門下圧 $\left(\mathrm{cmH}_{2} \mathrm{O}\right)$ 
を測定パラメーターとし，声門抵抗 $\left(\mathrm{cmH}_{2} \mathrm{O} /\right.$ $\mathrm{L} / \mathrm{sec}$ )，声門下パワー，音響エネルギー，さら に喉頭効率を求め, 正常喉頭者の成績と比較し たので，その成績について報告する.

\section{発声機能の検査方法}

1. 測定装置と発声機能パラメータ

本検査に用いたパラメータは，発声機能検査 装置 PS-772) から得られる音声の高さ $(\mathrm{Hz})$, 強 さ $(\mathrm{dB})$, 呼気流率 $(\mathrm{ml} / \mathrm{sec})$ と, 声門下圧である。 声門下圧測定は, ヨタカテ先端圧力センサー TCP2-RN13-6, F30 と micro tip catheter pressure trans-ducer (model PC-340, Miller 社) のいずれかを用い，経鼻的に声門下約 $3 \mathrm{~cm}$ に 先端部を固定し, 直接声門下圧を抽出した。こ の transducer の声門下への挿入による発声の 影響は殆どないこと3)を確認している.

以上のパラメータからコンピューター自動解 析システム PI-100 を用い, 声門抵抗 $\left(\mathrm{cmH}_{2} \mathrm{O}\right.$ $/ \mathrm{L} / \mathrm{sec})$, 声門下パワー $(\mathrm{erg} / \mathrm{sec})$, 音声パワー $(\mathrm{erg} / \mathrm{sec})$, 口端よりマイクの位置 $20 \mathrm{~cm}$ で, 環 境雑音を除去したもので喉頭効率（音声パワー /声門下パワー) を求め, これら 8 種のパラメー タを PS-77 装置の出力部より, 三栄測器 polygrapy 142-8, visigraph FR-102 に同時記録 させた。

また，画面上に一次，二次，三次元表示を可 能とし，これを印刷できるようにした。これら
の測定ダイヤグラムを図 1 に示した.

2 . 発声条件

日本音声言語医学会, 発声機能委員会の規約 に則り, 各被検者に, (1)深呼吸後, 最も出し易 い声の大きさと高さ（胸声区内）で，最長持続 発声を求めた。次いで，(2)被検者の出し得る声 の大きさを，弱い，普通，大きい声，できるだ け大きい声の 4 段階に分け，数秒間持続発声さ せた。 また，正常喉頭者の一部に音圧の变化を 連続発声下に行わせた。

3 . 対 象

喉頭癌19例を選択した。これは T1 5 例，T2 6 例, T3 6 例, T4 2 例であった. 対象として, 正常喉頭者 12 例（男性 9 例，女性 3 例）を選ん だ。本検査においてすべて患者の同意を得てい る.

\section{4. 成 績}

1) 最長持続発声の条件

正常喉頭ならびに喉頭癌症例, 声門癌 (T3N0 M0) の最長発声持続時の成績を図 2 と図 3 に 示す. 図 2 は，正常喉頭，24歳，女性で，彼女 の音声は高さ $185 \mathrm{~Hz}$, 強さは $90 \mathrm{~dB}$ であり, 最 長発声持続時間は 20.7 秒, 安定部分の平均呼気 流率は $106 \mathrm{ml} / \mathrm{sec}$, 声門下圧は $10.5 \mathrm{cmH}_{2} \mathrm{O}$ に て声門抵抗は $98.8 \mathrm{cmH}_{2} \mathrm{O} / \mathrm{L} / \mathrm{sec}$ ，喉頭効率は $2.91 \times 10^{-4}$ を得た。

図 3 は男性, 56歳, 声門癌 T3N0M0 で, 気

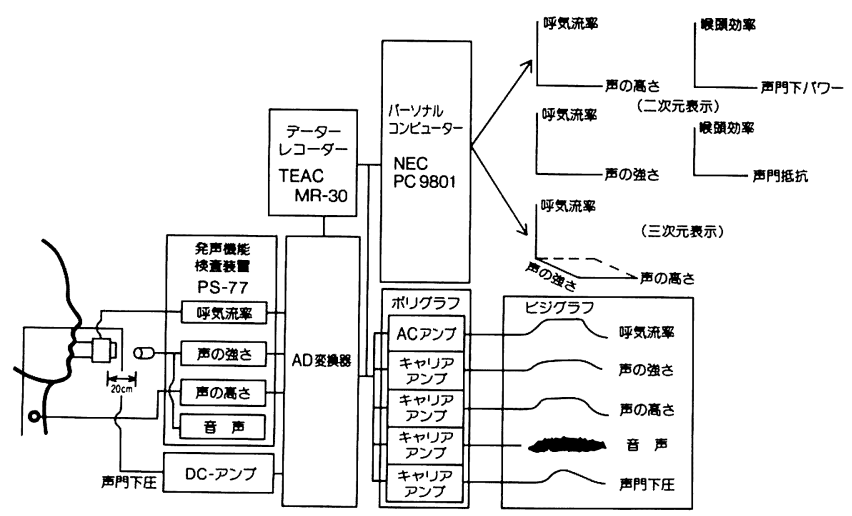

図 1 測定ダイアグラム 
息性と粗造性要素の強い嗄声で, 癌腫は右声帯 被裂部，仮声帯に浸潤し，右声帯固定がみられ た。検査時の音声の高さは， $170 \mathrm{~Hz}$ ，強さは 91
$\mathrm{dB}$ で，かなりの努力性発声の状態であった。 最長発声持続時間は13.8秒, 平均呼気流率は $155 \mathrm{ml} / \mathrm{sec}$ で声門下圧は $32.1 \mathrm{cmH}_{2} \mathrm{O}$ と増加し

正常喉頭
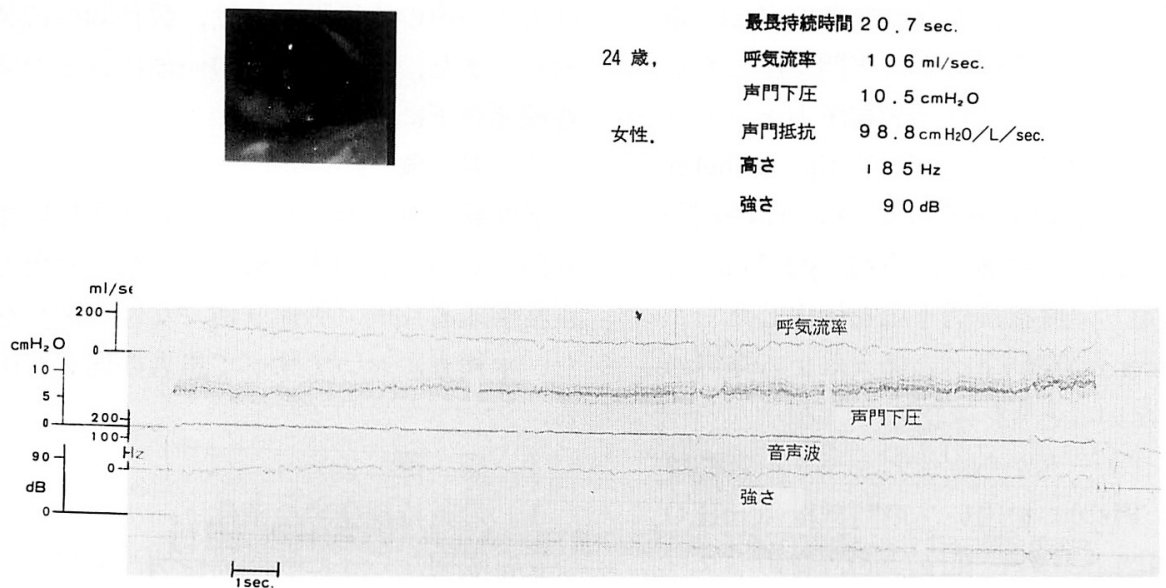

図 2 最長持続発声の音声 (高さ, 強さ), 呼気流率と声門下圧 発声中の各パラメータは安定してみられる.

喉 頭 癌

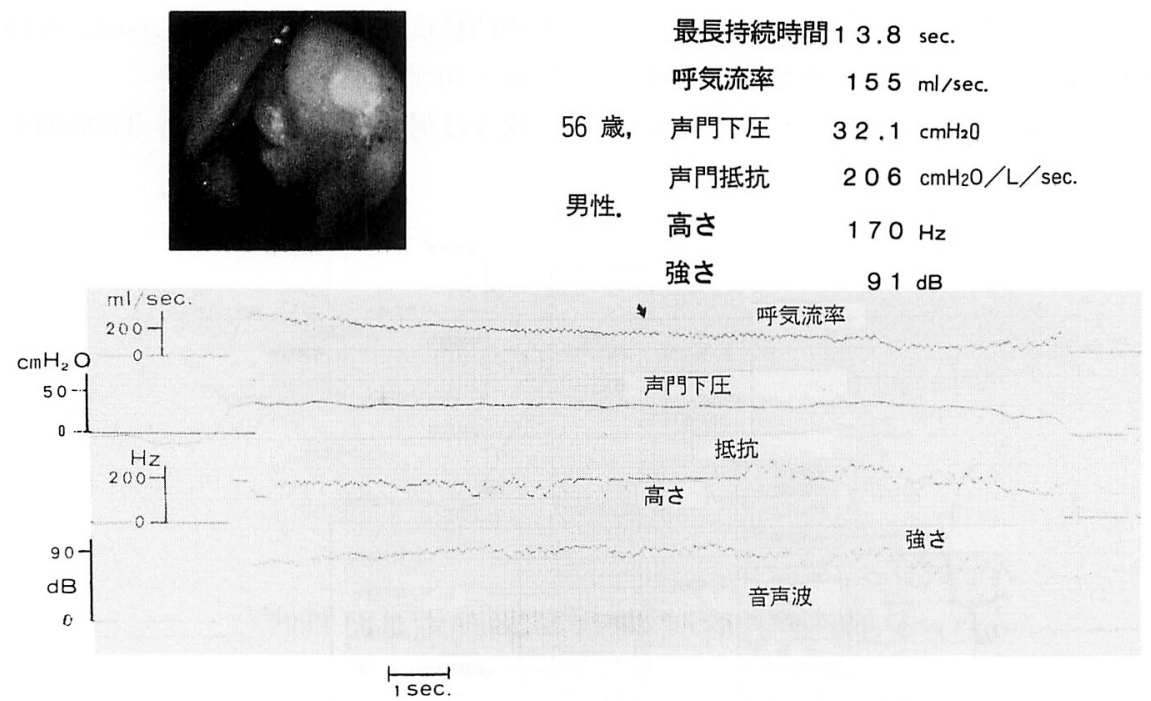

図 3 最長持続発声の音声 (高さ, 強さ), 呼気流率, 声門下圧, 声門抵抗 持続発声中の各パラメータの变動がみられる. 
ており, 声門抵抗は $206 \mathrm{cmH}_{2} \mathrm{O} / \mathrm{L} / \mathrm{sec}$, 喉頭 効率は $8.09 \times 10^{-4}$ であった。 また，この記録 にみる如く, 持続発声中に各パラメーターは不 規則に変動し特に起声時と終声時に著しかった．

各症例の持続発声時の安定部に护ける成績の 概要を正常喉頭と喉頭癌群に分け, 表 1 亿示し た. 正常喉頭に括ける最長発声持続時間の值は, 個々の肺機能の状態でやや異なっていたが，そ の平均值は $17.7 \pm 8.2$ 秒であり, 平均呼気流率 は症例 6 を除いて, その分布は $94 \mathrm{ml} / \mathrm{sec}$ から $215 \mathrm{ml} / \mathrm{sec}$ で, 平均値は $132.2 \pm 30.2 \mathrm{ml} / \mathrm{sec}$, その平均音圧は $75.8 \pm 6.6 \mathrm{~dB}$ であった.

声門下圧の分布は $5.1 \sim 14.7 \mathrm{cmH}_{2} \mathrm{O}$ で，そ の平均值は $10.2 \pm 3.1 \mathrm{cmH}_{2} \mathrm{O}$, 声門抵抗のそれ は $39 \sim 118 \mathrm{cmH}_{2} \mathrm{O} / \mathrm{L} / \mathrm{sec}$ にあり, その平均值 は $4.7 \pm 25.6 \mathrm{cmH}_{2} \mathrm{O} / \mathrm{L} / \mathrm{sec}$ を示し, その喉頭 効率は $0.1 \sim 2.91 \times 10^{-4}$ に分布し, その平均值 は $1.47 \pm 1.79 \times 10^{-4}$ となった。喉頭癌での M.P. T 平均値は, 声門癌 $\mathrm{T} 1 \mathrm{a}$ で $16.1 \pm 4.4$ 秒, $\mathrm{T} 2$ は $12.8 \pm 4.5$ 秒, T3 は $13.2 \pm 6.5$ 秒で, T4 は平均 15.8 秒であった。平均呼気流率の平均値 は, 声門癌 T1a は $178.0 \pm 84.9 \mathrm{ml} / \mathrm{sec}, \mathrm{T} 2$ は $177.2 \pm 58.0 \mathrm{ml} / \mathrm{sec}, \quad \mathrm{T} 3$ は $252.2 \pm 225.8$ $\mathrm{ml} / \mathrm{sec}, \mathrm{T} 4$ の平均値は $194.5 \mathrm{ml} / \mathrm{sec}$ を示した. 声門下圧は, T1a で $14.1 \sim 34.0 \mathrm{cmH}_{2} \mathrm{O}$ に認

表 1 最長持続発声時における発声機能 パラメータの平均值と標準偏差

\begin{tabular}{c|c|c}
\hline \hline & 正常喉頭 & 喉頭癌 \\
\hline $\begin{array}{c}\text { 最長発声持続時間 } \\
(\mathrm{sec})\end{array}$ & $\begin{array}{c}17.7 \pm 8.2 \\
(7.3-24.5)\end{array}$ & $\begin{array}{c}14.0 \pm 5.2 \\
(5.2-27.6)\end{array}$ \\
\hline $\begin{array}{c}\text { 平均呼気流率 } \\
(\mathrm{ml} / \mathrm{sec})\end{array}$ & $\begin{array}{c}132 \pm 30 \\
(94-304)\end{array}$ & $\begin{array}{c}196 \pm 129 \\
(65-280)\end{array}$ \\
\hline $\begin{array}{c}\text { 声門下厌 } \\
\left(\mathrm{cmH} \mathrm{H}_{2} \mathrm{O}\right)\end{array}$ & $\begin{array}{c}10.2 \pm 3.1 \\
(5.9-14.5)\end{array}$ & $\begin{array}{c}29.2 \pm 17.1 \\
(8.7-47.2)\end{array}$ \\
\hline $\begin{array}{c}\text { 声門抵抗 } \\
\left(\mathrm{cmH} \mathrm{H}_{2} \mathrm{O} / \mathrm{L} / \mathrm{sec}\right)\end{array}$ & $\begin{array}{c}74.7 \pm 25.6 \\
(39-118)\end{array}$ & $\begin{array}{c}191.6 \pm 153 \\
(44-640)\end{array}$ \\
\hline 強さ $(\mathrm{dB})$ & $\begin{array}{c}75.8 \pm 6.6 \\
(66.5-84.0)\end{array}$ & $\begin{array}{c}75.3 \pm 10.0 \\
(57.6-87.0)\end{array}$ \\
\hline 䐅頭効率 $10^{-4}$ & $\begin{array}{c}1.47 \pm 1.79 \\
(0.11-2.37)\end{array}$ & $\begin{array}{c}1.15 \pm 1.92 \\
(0.002-8.04)\end{array}$
\end{tabular}

め, その平均值は $25.5 \pm 8.0 \mathrm{cmH}_{2} \mathrm{O}, \mathrm{T} 2$ は $8.7 \sim 69.2 \mathrm{cmH}_{2} \mathrm{O}$ の範囲で, 平均值は $6.2 \pm$ $26.0 \mathrm{cmH}_{2} \mathrm{O}$ T3 は $10.8 \sim 37.9 \mathrm{cmH}_{2} \mathrm{O}$ に分布 し, その平均值は $32.1 \pm 18.6 \mathrm{cmH}_{2} \mathrm{O}$ となり, $\mathrm{T} 4$ の平均值は $36.0 \mathrm{cmH}_{2} \mathrm{O}$ であった. 喉頭癌 全症例の声門下圧の平均值は $29.2 \pm 17.1 \mathrm{cmH}_{2} \mathrm{O}$ となり, 正常喉頭に比し, 平均值で約 3 倍に増 加した.

喉頭癌全体の声門抵抗は194.6 $\pm 153.4 \mathrm{cmH}_{2} \mathrm{O}$ /L/sec で, 正常の約2.5倍を示した. T分類で は声門癌 T1a は $50 \sim 394 \mathrm{cmH}_{2} \mathrm{O} / \mathrm{L} / \mathrm{sec}$ に分布 し, その平均值は $165.2 \pm 129.3 \mathrm{cmH}_{2} \mathrm{O} / \mathrm{L} / \mathrm{sec}$ となり, T2 は $44 \sim 640 \mathrm{cmH}_{2} \mathrm{O} / \mathrm{L} / \mathrm{sec}$ の範囲 で, その平均値は $257.7 \pm 224.8 \mathrm{cmH}_{2} \mathrm{O} / \mathrm{L} / \mathrm{sec}$ と声門抵抗は増大していた. これに反し, T3, 4 症例は $23 \sim 317 \mathrm{cmH}_{2} \mathrm{O} / \mathrm{L} / \mathrm{sec}$ の間に分布し, その平均值は $151.4 \pm 95.9 \mathrm{cmH}_{2} \mathrm{O} / \mathrm{L} / \mathrm{sec}$, T1a, T2 に比し, やや抵抗していた. 喉頭効率 は全体で $1.05 \pm 1.82 \times 10^{-4}$ を示し, 正常に比 べ低下し，その程度は，T1a では平均 $1.22 \pm$ $0.58 \times 10^{-4}, \mathrm{~T} 2$ では $0.48 \pm 0.73 \times 10^{-4}, \mathrm{~T} 3,4$ では $0.48 \pm 0.72 \times 10^{-4}$ と, 癌の進展の程度に つれて低下していた.

2 ) 声の強さの変化

声の強さを変化させた時の, 正常喉頭と喉頭 癌症例の各パラメータの变化を表 2,3 に示寸. 一般的に両群とも音声を強く発声させると, 声 門下圧の増加, 呼気流率の増加を示し, 声門抵 抗も増加し, 喉頭効率も上昇していた. 声門下 圧と音圧の関係は, 正常喉頭では図 4-1 亿示 す如く, 音圧が増加するにしたがい声門下圧も 直線的に増加し，その両者間に密接な相関関係 を認めた $(\mathrm{r}=0.99)$. 図 4-2 は, 喉頭癌症例 $\mathrm{T} 2$ N0M0 の声門下圧と音圧の関係を示した. 喉頭 癌では声門下圧は高く, 声帯の病変の程度によ り, 音圧と声門下圧の測定值は異なるも, 両者 間には正の相関が $(r=0.76)$ 認められた.

正常喉頭之喉頭癌症例に打ける声門下圧と喉 頭効率の関係は, 図 5-1, 5-2 に示す如く, 両群之も声門下圧は増加につれ喉頭効率も上昇 
し，直線的な密接な関係 $(\mathrm{r}=0.98)$ を認めた.

声の大きさと喉頭効率は密接な直線的関係 ${ }^{16)}$ を示すも, 声帯病変の程度により, この相互関 係の程度は異なっていた。

正常喉頭之喉頭癌の各症例について, 声の強 さの変化 $(\mathrm{dB})$ と声門下圧の相互関係を, 図 6 に示した. 両者を比較すると, 正常喉頭(図 61 ) に比し, 癌症例 (図 6-2) では声門下圧は高 く，声を大きくすると急激に増加したが，出し
得る音圧 $(\mathrm{dB})$ の範囲が狭くなってきていた. 音圧レベルと喉頭効率との関係は図 7 に示す如 く, 正常喉頭(図 7-1) の喉頭効率の範囲は, $0.1 \times 10^{-4}$ から $41.5 \times 10^{-4}$ の範团で増加した。 喉頭癌 (図 7-2) では $0.005 \times 10^{-4}$ から $16.5 \times$ $10^{-4}$ の範囲内にあり声門癌の進展の程度によ り著しく相違し, 音圧変動範囲の減少と $\mathrm{T} 3, \mathrm{~T} 4$ 症例に，喉頭効率低下を認めた.

表 2 変化発声（正常喉頭）

\begin{tabular}{|c|c|c|c|c|c|c|c|c|}
\hline 症例 & 年歯 & 性別 & $\begin{array}{c}\text { 呼気流率 } \\
\mathrm{ml} / \mathrm{sec}\end{array}$ & $\begin{array}{l}\text { 声門下厌 } \\
\mathrm{cmH}_{2} \mathrm{O} \\
\end{array}$ & \begin{tabular}{|c|} 
喉頭抵抗 \\
$\mathrm{cmH}_{2} \mathrm{O} / \mathrm{l} / \mathrm{sec}$ \\
\end{tabular} & $\begin{array}{c}\text { 周波数 } \\
\mathrm{Hz}\end{array}$ & ${ }_{\mathrm{dB}}^{\text {音圧 }}$ & $\begin{array}{c}\text { 喉頭効率 } \\
\times 10^{-4} \\
\end{array}$ \\
\hline \multirow{2}{*}{1} & \multirow{2}{*}{75} & \multirow{2}{*}{ 男 } & 106 & 16.7 & 157 & 160 & 91.0 & 23.1 \\
\hline & & & 141 & 17.5 & 124 & 180 & 95.0 & 41.5 \\
\hline \multirow{2}{*}{2} & \multirow{2}{*}{24} & \multirow{2}{*}{ 男 } & 94 & 9.6 & 102 & 170 & 82.0 & 5.50 \\
\hline & & & 200 & 23.0 & 115 & 260 & 90.0 & 7.02 \\
\hline \multirow{2}{*}{3} & \multirow{2}{*}{76} & \multirow{2}{*}{ 男 } & 246 & 16.4 & 67 & 142 & 76.7 & 0.38 \\
\hline & & & 308 & 28.9 & 94 & 196 & 86.5 & 1.62 \\
\hline \multirow{2}{*}{4} & \multirow{2}{*}{25} & \multirow{2}{*}{ 男 } & 196 & 3.9 & 20 & 88 & 68.7 & 0.32 \\
\hline & & & 500 & 47.9 & 96 & 210 & 98.0 & 8.56 \\
\hline \multirow{2}{*}{5} & \multirow{2}{*}{29} & \multirow{2}{*}{ 男 } & 128 & 6.8 & 53 & 220 & 72.9 & 0.75 \\
\hline & & & 164 & 34.0 & 532 & 100 & 87.0 & 7.47 \\
\hline \multirow{2}{*}{6} & \multirow{2}{*}{73} & \multirow{2}{*}{ 男 } & 348 & 12.7 & 37 & 108 & 71.0 & 0.09 \\
\hline & & & 348 & 25.0 & 72 & 208 & 87.0 & 1.85 \\
\hline \multirow{2}{*}{7} & \multirow{2}{*}{29} & \multirow{2}{*}{ 男 } & 217 & 3.6 & 17 & 93 & 70.5 & 0.47 \\
\hline & & & 283 & 12.1 & 43 & 123 & 84.5 & 2.64 \\
\hline \multirow{2}{*}{8} & \multirow{2}{*}{65} & \multirow{2}{*}{ 男 } & 167 & 6.1 & 37 & 123 & 68.2 & 0.21 \\
\hline & & & 69 & 13.3 & 192 & 123 & 76.2 & 1.48 \\
\hline \multirow{2}{*}{9} & \multirow{2}{*}{51} & \multirow{2}{*}{ 女 } & 127 & 8.9 & 70 & 216 & 76.8 & 1.38 \\
\hline & & & 253 & 26.3 & 104 & 284 & 87.5 & 2.73 \\
\hline \multirow{2}{*}{10} & \multirow{2}{*}{38} & \multirow{2}{*}{ 女 } & 233 & 15.8 & 68 & 156 & 87.0 & 4.37 \\
\hline & & & 317 & 21.1 & 66 & 208 & 96.0 & 19.3 \\
\hline \multirow{2}{*}{11} & \multirow{2}{*}{49} & 女 & 324 & 9.7 & 30 & 233 & 79.3 & 0.89 \\
\hline & & x & 412 & 15.3 & 37 & 262 & 89.5 & 4.57 \\
\hline 12 & -5 & 田 & 222 & 4.9 & 22 & 131 & 75.5 & 0.91 \\
\hline 12 & 51 & 劣 & 264 & 15.9 & 60 & 123 & 90.0 & 7.73 \\
\hline
\end{tabular}


考察

発声機構に関する研究は, 声帯の振動動態や 音響学的分析, ならびに空気力学的な面より追 求されてきている。
今回我々が開発した発声機能自動解析システ 么 $(\mathrm{PI}-100)^{1)}$ を用い, 喉頭癌 (声門癌) を対象 に，その声門下王の同時測定から声門抵抗，声 門下パワー, 喉頭効率を求め, 正常喉頭者と比

表 3 変化発声 (喉頭癌)

\begin{tabular}{|c|c|c|c|c|c|c|c|c|c|}
\hline 症例 & 年齢 & 性別 & 病期 & $\begin{array}{c}\text { 呼気流率 } \\
\mathrm{ml} / \mathrm{sec}\end{array}$ & $\begin{array}{l}\text { 声門下压 } \\
\mathrm{cmH}_{2} \mathrm{O}\end{array}$ & $\begin{array}{c}\text { 喉頭抵抗 } \\
\mathrm{cmH}_{2} \mathrm{O} / \mathrm{l} / \mathrm{sec}\end{array}$ & $\begin{array}{c}\text { 周波数 } \\
\mathrm{Hz}\end{array}$ & $\begin{array}{l}\text { 音压 } \\
\mathrm{dB}\end{array}$ & $\begin{array}{l}\text { 喉頭効率 } \\
\times 10^{-4} \\
\end{array}$ \\
\hline \multirow{2}{*}{ (1) } & \multirow{2}{*}{65} & \multirow{2}{*}{ 男 } & \multirow{2}{*}{$\mathrm{T}_{\mathrm{la}}$} & 129 & 11.3 & 88 & 115 & 81.5 & 3.13 \\
\hline & & & & 300 & 35.6 & 119 & 185 & 92.0 & 4.81 \\
\hline \multirow{2}{*}{ (2) } & \multirow{2}{*}{56} & \multirow{2}{*}{ 男 } & \multirow{2}{*}{$\mathrm{T}_{\mathrm{la}}$} & 192 & 26.0 & 135 & 156 & 71.1 & 0.08 \\
\hline & & & & 231 & 40.8 & 177 & 200 & 82.0 & 0.54 \\
\hline \multirow{2}{*}{ (3) } & \multirow{2}{*}{73} & \multirow{2}{*}{ 男 } & \multirow{2}{*}{$\mathrm{T}_{1 \mathrm{a}}$} & 230 & 13.6 & 59 & 175 & 79.5 & 0.91 \\
\hline & & & & 500 & 81.5 & 163 & 466 & 86.5 & 0.35 \\
\hline \multirow{2}{*}{ (4) } & \multirow{2}{*}{50} & \multirow{2}{*}{ 女 } & \multirow{2}{*}{$T_{1 a}$} & 130 & 13.9 & 106 & 147 & 63.6 & 0.04 \\
\hline & & & & 174 & 39.0 & 224 & 286 & 81.5 & 0.66 \\
\hline \multirow{2}{*}{ (5) } & \multirow{2}{*}{53} & \multirow{2}{*}{ 男 } & \multirow{2}{*}{$\mathrm{T}_{1 \mathrm{a}}$} & 480 & 11.1 & 23 & 185 & 70.9 & 0.08 \\
\hline & & & & 440 & 31.2 & 71 & 115 & 80.0 & 0.23 \\
\hline \multirow{2}{*}{ (6) } & \multirow{2}{*}{70} & \multirow{2}{*}{ 男 } & \multirow{2}{*}{$\mathrm{T}_{2}$} & 257 & 9.0 & 35 & 115 & 74.2 & 0.37 \\
\hline & & & & 971 & 130.5 & 134 & 330 & 94.0 & 0.64 \\
\hline \multirow{2}{*}{ (7) } & 59 & 男 & $T_{0}$ & 231 & 36.2 & 157 & 165 & 86.5 & 1.72 \\
\hline & 59 & 力 & $1_{2}$ & 487 & 72.5 & 149 & 233 & 91.0 & 1.15 \\
\hline & & & & 269 & 23.3 & 87 & 82 & 63.4 & 0.01 \\
\hline (8) & 56 & 男 & $\mathrm{I}_{2}$ & 154 & 23.3 & 151 & 120 & 67.8 & 0.06 \\
\hline (9) & 64 & 男 & $T_{2}$ & 189 & 96.4 & 509 & 150 & 64.7 & 0.005 \\
\hline (9) & 04 & 劣 & $I_{2}$ & 162 & 68.0 & 419 & 170 & 80.5 & 0.33 \\
\hline 10 & 59 & 男 & $T_{0}$ & 120 & 12.8 & 107 & 93 & 62.4 & 0.04 \\
\hline (10) & 59 & 力 & $1_{2}$ & 360 & 36.8 & 102 & 220 & 83.0 & 0.48 \\
\hline (11) & 60 & 男 & $T_{2}$ & 240 & 25.2 & 105 & 156 & 70.7 & 0.06 \\
\hline (11) & 00 & 力 & $1_{2}$ & 320 & 50.5 & 158 & 131 & 75.5 & 0.07 \\
\hline & & & & 267 & 32.1 & 121 & 170 & 90.0 & 3.74 \\
\hline (12) & 56 & 男 & $1_{3}$ & 289 & 67.9 & 235 & 260 & 100.0 & 16.5 \\
\hline & & & & 811 & 15.2 & 19 & 110 & 84.0 & 0.66 \\
\hline (13) & by & 男 & $1_{3}$ & 919 & 23.4 & 26 & 262 & 88.5 & 1.06 \\
\hline (14) & 71 & 男 & & 272 & 31.4 & 116 & 131 & 69.7 & 0.04 \\
\hline (14) & 11 & 力 & $1_{3}$ & 109 & 29.9 & 275 & 150 & 72.7 & 0.19 \\
\hline (15) & 73 & 男 & $T_{3}$ & 207 & 28.1 & 136 & - & 64.4 & 0.02 \\
\hline (12) & 15 & 力 & $1_{3}$ & 435 & 24.5 & 56 & - & 69.5 & 0.03 \\
\hline (16) & 73 & 男 & $T_{3}$ & 167 & 15.5 & 93 & 120 & 78.4 & 0.87 \\
\hline (10) & 15 & 力 & $1_{3}$ & 233 & 38.8 & 166 & 156 & 87.0 & 1.76 \\
\hline (17) & 63 & 男 & & 348 & 16.7 & 48 & 65 & 60.1 & 0.006 \\
\hline (11) & b3 & 劣 & $1_{3}$ & 435 & 26.3 & 60 & 104 & 61.6 & 0.004 \\
\hline & & & & 143 & 17.2 & 120 & 125 & 76.0 & 0.53 \\
\hline (18) & bl & 男 & $1_{4}$ & 191 & 37.2 & 195 & 160 & 85.5 & 1.62 \\
\hline (19) & 67 & 男 & $\mathrm{T}_{4}$ & 179 & 10.6 & 59 & 147 & 74.1 & 0.45 \\
\hline & 01 & 力 & $1_{4}$ & 372 & 41.4 & 111 & 262 & 92.5 & 3.75 \\
\hline
\end{tabular}


較検討した。喉頭での発声時の声門下王の直接 測定は, 特に声門抵抗を数量的に求めることが 可能で, 臨床的に機能的診断を下寸うえで極め て重要となる。

そこで微細圧力計 micro tip TCP2-RN13 や, micro tip PC-340 (Miller 社)を用い13) 経鼻的に
圧センサーを声門下 $3 \mathrm{~cm}$ に挿入し，発声機能 検査装置 (PS-77) と連動させ, PI-100 自動解析 プログラムを用い，各パラメータ間の相互関係 を追求した。

声門下圧と音圧との関係は，Van den Berg $5^{4) 5)}$, Isshiki' ${ }^{6}$, Ladeforged ${ }^{7)}$, Prakashpixit $5^{8)}$

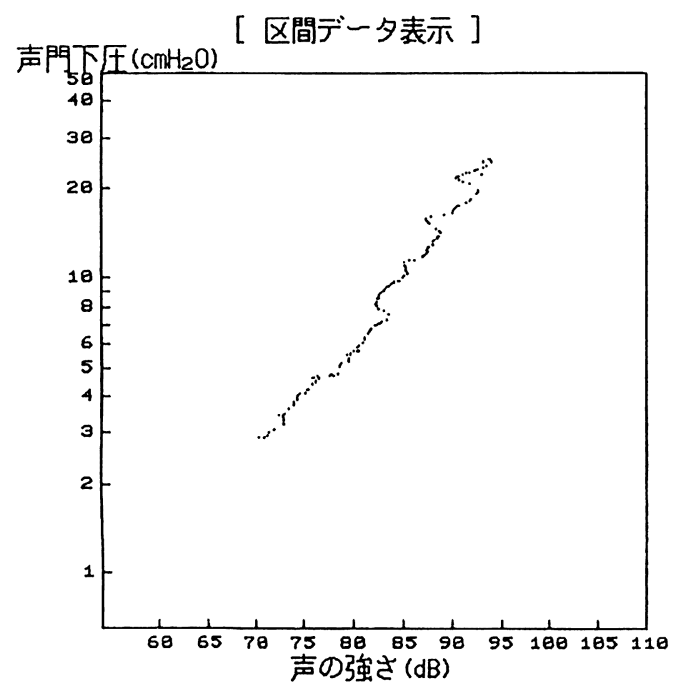

図 4-1 正常喉頭

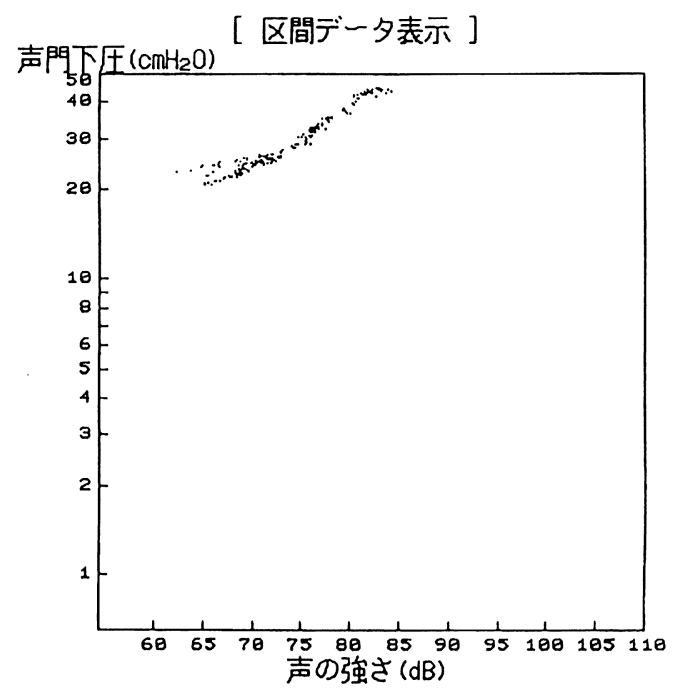

図 4-2 喉頭癌 $\mathrm{T} 2 \mathrm{~N} 0 \mathrm{M} 0$

図 4 声の大きさと声門下圧との関係

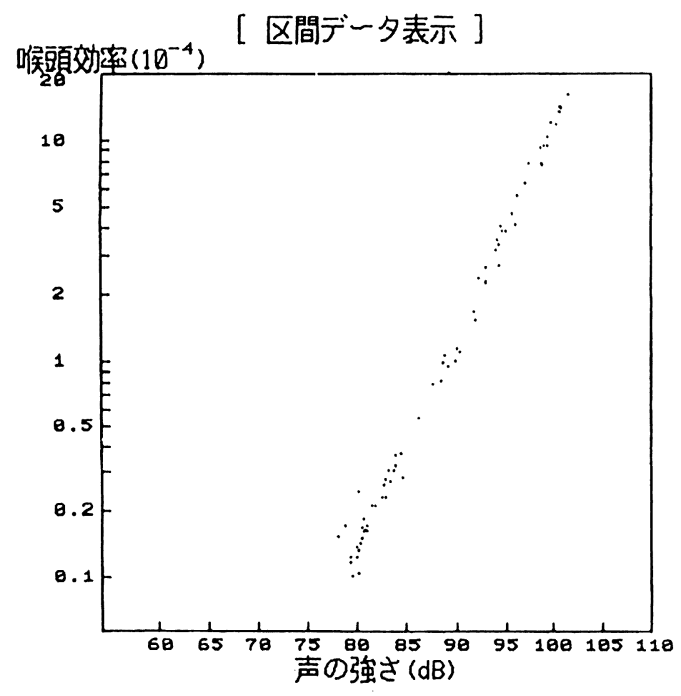

図 5-1 正常喉頭

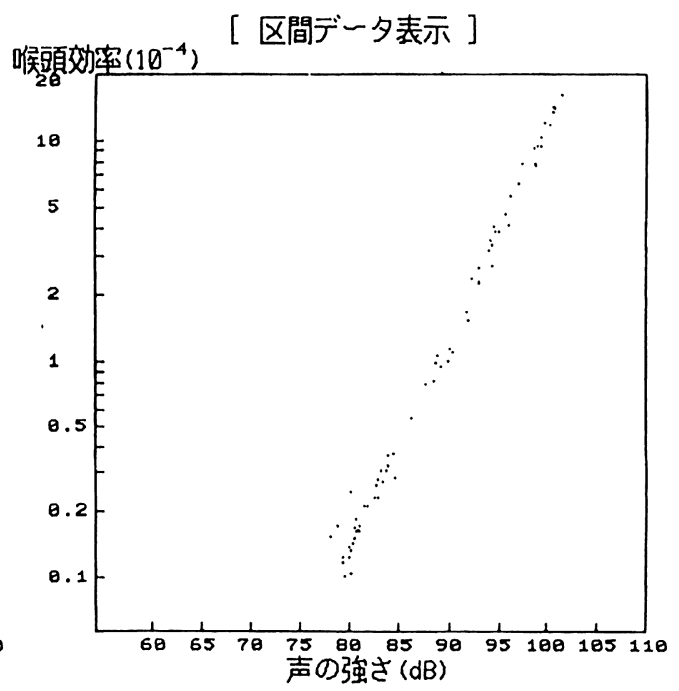

図 5-2 喉頭癌 T2N0M0

図 5 声の大きさと喉頭効率の関係 
が，正の直線的関係のあることを報告したが， 我々の正常ならびに病的喉頭での成績もこれを 支持した. 発声機能を評価するに当たり，どの パラメータを基準とするかについては，まだ議 論のあるところである.今回, 持続発声時と音 声の強さを変えた場合の発声機能を, 生理学的, 空気力学的な面から検討を加えた. 臨床的に声 門下圧を簡単に測定できなかったため，代用と して, 食道内圧 ${ }^{678)}$, 気管刺穿799), 気流阻止 法10) 12)，気管切開孔の利用9113)により，声門 の状態や呼気努力状態を推定してきた. 声門下 圧を経声門的に直接測定することが可能とな

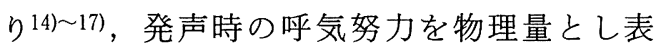

示，声門閉塞の状態を声門抵抗（声門下圧/呼 気流率）で求めることが可能となった。その結 果, さらに声門下パワーから音声波へのエネル ギーの転換の割合すなわち喉頭効率4)5) を求め ることができた．正常喉頭被検者の最も出し易 い声で，持続発声時の声門下圧は， $5.1 \mathrm{cmH}_{2} \mathrm{O}$ から $14.7 \mathrm{cmH}_{2} \mathrm{O}$ の間にあり，その平均值は $10.2 \pm 3.1 \mathrm{cmH}_{2} \mathrm{O}$ であった. 声門抵抗は, 理 論的には声帯振動サイクルごとに，声門上下圧 差を呼気流率で割った值で示されるが，我々は 平均声門抵抗を，声門下圧を呼気流率で割った 值として133) 5)16)18) 求めた. 正常喉頭の抵抗は 44 104 $\mathrm{cmH}_{2} \mathrm{O} / \mathrm{L} / \mathrm{sec}$ の範囲を示し, その值

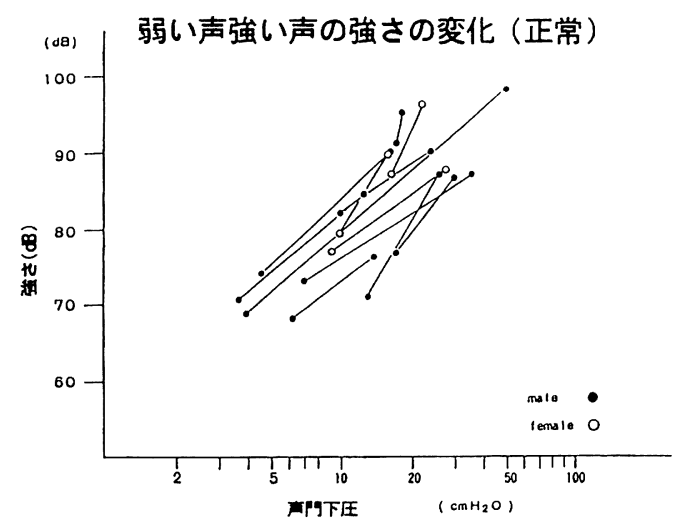

図 6-1

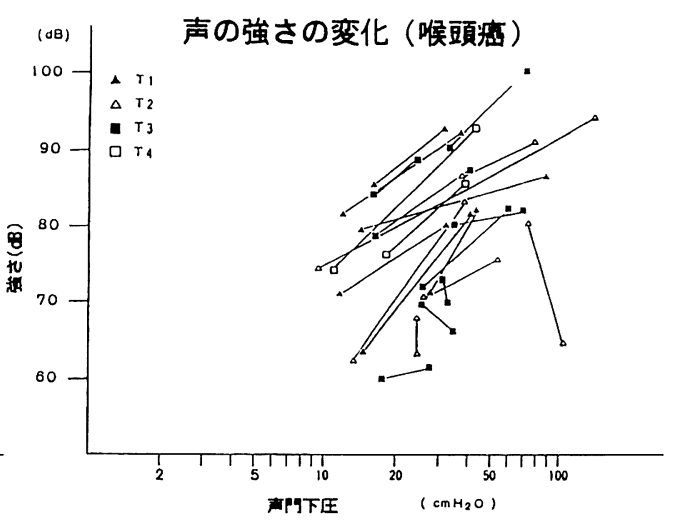

図 6-2

図 6 声の大きさと声門下圧の関係

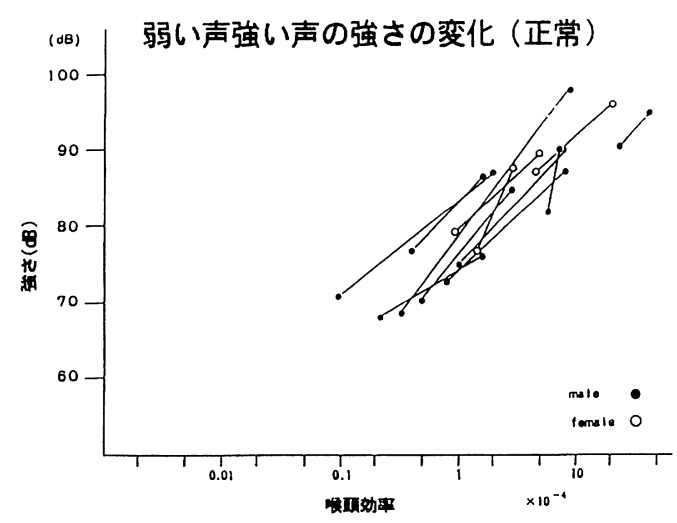

図 7-1

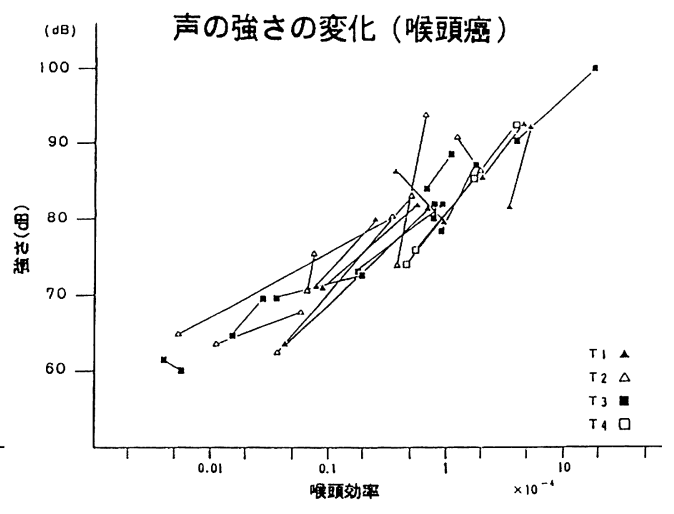

図 $7-2$

図 7 声の大きさと喉頭効率の関係 
は声の強さ $(\mathrm{dB})$ と直線的な一次的関係を有し ていた. 声門癌では, 黒木 ${ }^{19)}$ は $41 \sim 73 \mathrm{cmH}_{2} \mathrm{O}$ /L/sec の範囲であったと報告したが，我々の 成績は, T1a 症例は $50 \sim 394 \mathrm{cmH}_{2} \mathrm{O} / \mathrm{L} / \mathrm{sec}$ の 間 T2 は 44 640 $\mathrm{cmH}_{2} \mathrm{O} / \mathrm{L} / \mathrm{sec}, \mathrm{T} 3$ は 23〜 $317 \mathrm{~cm}$ $\mathrm{H}_{2} \mathrm{O} / \mathrm{L} / \mathrm{sec}$ の範囲で, 正常喉頭に比し, 明ら かに増大していた. 声帯固定を示す T3 では, 腫瘍による声門閉塞の障害の程度により, 著し く異なった值を示した。この点に関し，Van den Berg ら ${ }^{5)}$ は, 摘出喉頭で実験的に声帯固 定をした場合で，著しい呼気流率と声門下圧の 増加は声門面積が大となり, 雑音成分の増加か ら良い音声にはならないとし，その限界を流量 $400 \mathrm{ml} / \mathrm{sec}$ 声門下圧 $20 \sim 30 \mathrm{cmH}_{2} \mathrm{O}$ とした。 た, 持続発声時では, 発声時の声門下圧の急激 な上昇傾向と, 発声中高い声門下圧を必要とし, 声門癌 $\mathrm{T} 2$ 以上の浸潤を来すと, その圧变動が 不規則となる特徵を示した。

喉頭効率は, 正常喉頭は Isshiki6) は $0.9 \sim$ $4.0 \times 10^{-4}$, Van den Berg ${ }^{4)}$ は 0.2 2.5 $\times 10^{-5}$, 西田 ${ }^{11)}$ は $1.9 \sim 7.2 \times 10^{-4}$ としたが, 今回の成 績は0.11から $29.1 \times 10^{-4}$ の範囲で, その平均 は $1.05 \pm 1.82 \times 10^{-4}$ であった。

声門癌では T1a は $0.90 \sim 2.09 \times 10^{-4}, \mathrm{~T} 2$ は $0.002 \sim 1.72 \times 10^{-4}$, T3 は $0.003 \sim 8.09 \times 10^{-4}$ に分布し, 正常喉頭に比し低下したものを約半 数に認めた. 声の強さの調節機構(は9)13)，呼気
努力（声門下圧, 呼気流量）と声門閉塞力（抵 抗）とに分けられる. 例えば，声門部の閉塞力 が一定で呼気努力を増せば，声門下圧，呼気流 率とも増加するが，呼気努力が一定ならば，声 門閉塞力を強めれば声門下圧は上昇するも，呼 気流率は不変か，低下すること7111)になる。そ こで, 正常喉頭ならびに喉頭癌症例に捺ける声 の強さの調整について, 発声時の声門下圧, 呼 気流率, 声門抵抗, 喉頭効率の変動の関係を表 4 に示した.

正常喉頭ではすべてのパラメータの増加を示 したもの $98 \%$ に, 喉頭癌では $57.9 \%$ に認め, 呼 気流率の不変，または低下のみ示したものは正 常喉頭で 1 例, 喉頭癌で 3 例 (27.3\%) であっ た。

一方，声の大きさを増加させると，声門下圧 が低下したものを 4 例（8.2\%）に認め，らち 声門抵抗の増加は 2 例, 低下を来したものは 2 例であった。この 4 症例はいずれも弱い声の状 態から，すでに高い声門下圧 $51.0 \pm 26.9 \mathrm{cmH}_{2}$ O を示して扣り，大きな声が出し難く，喉頭効 率はほとんど変化を示さなかった。

以上，声門下圧と呼気流率を測定することに より, 声門の機能状態を具体的に理解出き発声 方法を変え，喉頭効率を求めることにより，声 門部の病変による発声障害の程度をより, 詳細 に，客観的に評価し得るものと考えた.

表 4 空気力学的にみた発声時喉頭調節

\begin{tabular}{|c|c|c|c|c|c|c|c|c|}
\hline 声門下圧 & 声門抵抗 & 呼気流率 & 喉頭効率 & 正常 & T1a & $\mathrm{T} 2$ & $\mathrm{~T} 3$ & $\mathrm{~T} 4$ \\
\hline \multirow{3}{*}{ 増 } & \multirow{2}{*}{ 増 } & 増 & 増 & 11 & 4 & 3 & 2 & 2 \\
\hline & & 不変 (減) & 増 & 1 & 1 & 1 & 1 & \\
\hline & 不変 (低下) & 増 & 増 & & & 1 & & \\
\hline \multirow{4}{*}{ 不変 (低下) } & \multirow{2}{*}{ 増 } & 増 & 増 & & & & 1 & \\
\hline & & 不変 (低下) & 不変 & & & & 1 & \\
\hline & \multirow{2}{*}{ 低下 } & 増 & 不変 & & & & 1 & \\
\hline & & 低下 & 不変 & & & 1 & & \\
\hline
\end{tabular}

但し，T2の弱い発声より声門下圧，声門抵抗は極めて高い値を示していた 


$$
\text { まとめ }
$$

1. 正常喉頭12例と喉頭癌19例につき，声門 下王を直接経声門的に測定し, PS-77 装置にて 呼気気流，高さと強さを同時記録し声門抵抗， 声門下パワー，喉頭効率を求めた。

2. 持続発声時の声門下圧は, 正常喉頭で平 均 $10.2 \pm 3.1 \mathrm{cmH}_{2} \mathrm{O}$ を示し, 喉頭癌では著し く増加し, 発声中, 圧変動が不規則にみられた。

3. 持続発声時の喉頭効率は, 正常喉頭は $0.1 \sim 29.1 \times 10^{-4}$ の範囲にあり, 喉頭癌に拈け る平均値は $1.05 \times 10^{-4}$ と低下していた。

4. 声を大さくさせた場合，正常喉頭，喉頭 癌 T1, T2 では, 声門下圧, 抵抗, 喉頭効率も 直線的に増加したが，声門癌，特に T3，T4で は弱い声でも声門下王は著しく高く，声門抵抗 も異なり，喉頭効率の上昇を認めないものがあ った。

\section{文 献}

1) 岩田重信, 大津有二郎, 小島秀嗣, 他: 発声機 能自動解析システム (PI-100) そついて. 音声言 語医学 $32: 406 \sim 412,1991$.

2）沢島政行, 青木幸夫 : 発声時の呼気流率の高さ および強さの同時測定装置. 医科器械学 52 : 342 345, 1982.

3）畔柳久志 : 正常ならびに喉頭癌患者の発声機能. 藤田医学誌 $4: 165 \sim 211,1985$.

4) Van den Berg J : Direct and indirect determination of the mean subglottic pressure. Folia Phoniat $8: 1 \sim 24,1956$.

5) Van den Berg J and Tan TS : Results of experiment with human larynxes. Pract Rhinol Laryngol $21:$ 425 450, 1959.

6) Issiki $N$ : Regulatory mehanism of voice intensity variation. J Speech Hearing Res $7: 17$ $\sim 29,1964$.

7) Ladeforged P and Mckinney NP : Loudness, sound pressure, and subglottic pressure in speech. J Acoust Soc Am 35 : 454 460, 1963.

8) Dixit PP and Shipp $T$ : Study of subglottal air pressure during Aindi stop consonants. Phonetica $42: 53 \sim 77,1985$.

9）廣戸幾一郎：発声機構の面よりみた喉頭の病態 生理. 耳鼻臨床 59 増 $1: 229 \sim 292,1966$.

10）西田之昭, 周防屋洋: 発声時声門下圧測定法 一食道内圧測定法と気流阻止法一. 耳鼻 10 : $264 \sim 270,1927$.

11）西田之昭：喉頭の効率. 音声言語医学 $7: 29$ ～ 34, 1966.

12）沢島政行, 本多清志, 青木幸夫 : 気流阻止法を 利用した発声時の空気力学的検査法. 音声言語 医学 $28: 257 \sim 264,1987$.

13）平野 実: 音声外科の基礎と臨床. 耳鼻 21 : 239 442, 1975.

14) Koike $Y$ and Perkins WH : Application of a miniaturied pressure transducer for experimental speech research. Folia Phoniatr $20: 360 \sim$ 368, 1968.

15）小池靖夫 : 声門下圧直接測定法とその応用. 音 声言語医学 $19: 212 \sim 216,1978$.

16）渡辺 宏, 小宮山荘太郎, 西納真介, 他: 小型 拡散型半導体を用いた声門下圧測定法. 音声言 語医学 $19: 224 \sim 227,1978$.

17) Cranen $B$ and Boves $L$ : Pressure measurements during speech production using semiconductor miniature pressure transducers ; impact on models for speech-production. J Acoust Soc Am $77:$ 1543 1551, 1985.

18) Iwata $S:$ Aerodynamic studies in pathologic larynges. Vocal Physiology 2: 423 432, (Raven) 1988.

19）黑木康二 : 発声時の声門下王に関する研究. 耳 鼻 15 補 $1:$ 54 74, 1969.

$\left(\begin{array}{l}\text { 別刷請求先 : 岩田重信 } \\ \text { 干470-11 豊明市沓掛町田楽ケ窪1-98 } \\ \text { 藤田保健衛生大学医学部耳鼻咽喉科学教室 }\end{array}\right)$ 